\title{
„А ШТА АКО СУ И ТЕБЕ ИЗМИСЛИЛИ, АКО ЈЕ И ТВОЈ ЖИВОТ САМО КҢИГА?”
}

\author{
Интертекстуалност и метафикција у прози Попа Д. Ђурђева² \\ I'm so sorry for that ghost I made you be \\ Only one of us was real and that was me
}

Leonard Cohen, Treaty

\begin{abstract}
Малобројни прозни текстови Попа Д. Ђурђева су, као и његова поезија, изразито интертекстуални. Различити облици цитатности, пародија и иронија најчешћи су видови испољавања интертекстуалности ове прозе. Како се према Патриши Во (Patricia Waugh) ови елементи могу посматрати и као видови метафикције, писања које „самосвесно и систематски скреће пажњу на свој статус артефакта”, можемо закључити да је проза Попа Д. Ђурђева и метафикционална. Али она је то и у другом, ужем значењу појма метафикције: у неким текстовима, пре свега у Лету лионског Икара, тематизује се питање односа стварности и фикције на начин типичан за постмодерно поимање ауторске самосвести: Ко је кога измислио, аутор јунака или јунак аутора?
\end{abstract}

Кључне речи: Поп Д. Ђурђев, Антоан де Сент Егзипери, интертекстуалност, метафикција, постмодерна, ружа, смрт

У приручнику Тумачење књижевности за деиу који је уредио Питер Хант (Peter Hunt) ${ }^{3}$, текстови који потпадају под појам метафикције и експериментисање текстом означени су као „текстови вишег реда” (MEKALUM 2013: 215). Исто би се могло рећи и за присуство интер-

\footnotetext{
${ }^{1}$ mirjana.kararanovic22@gmail.com

2 Рад је саопштен на Округлом столу „Интертекстуалност и интермедијалност у књижевном делу за децу Попа Д. Ђурђева”, одржаном 22. марта 2019. на Филозофском факулету у Нишу.

${ }^{3}$ Understanding Children's Literature, Routledge, London 1999. Превод на српски: Тумачене кюижевносии за деиу. Уредио Питер Хант. Приредила и пропратне текстове написала Зорана Опачић, превела Наташа Јанковић. Учитељски факултет, Београд 2013.
} 
текстуалности у књижевности за децу. У оба случаја ради се о усмерености књижевних дела не на „стварност” већ на друге текстове. Такав приступ захтева читаоца који такву међутекстовну игру разуме. Управо зато, иако је данас метафикција поздрављена и прихваћена, она и даље изазива скептицизам и отпор. Обично се чују коментари да је овај жанр исувише тежак за децу. Али метафикција може да има и инструктивни карактер, и да учи младе читаоце „како се структура текстова формира путем специфичних кодова и конвенција" (MEKALUM 2013: 219). Тиме они постају компетентнији читаоци. Што се тиче Попа Д. Ђурђева, он ту нема нарочите дилеме: он такав ангажман читалаца отворено захтева на пример, поднаслов књиге $О$ бабама и жабама гласи „Минијатуре за основце са високом стручном спремом".

Доста је писано о интертекстуалности у поезији Попа Д. Ђурђева. Штавише, тешко да је могуће не поменути испреплетеност текстова и усмереност на „културу књиге” у било каквом осврту на дело овог писца. Може се рећи да је интертекстуалност доминанта његовог опуса. Песничког, свакако, али и прозног. Овај потоњи је обимом много скромнији - ако не рачунамо прозне записе у периодици, у прозу Попа Д. Ђурђева убрајају се свега четири наслова: сатира Вавилонски неимари (1984), кратак роман ${ }^{4}$ Лет лионског Икара (2010), аутобиографски запис Тамо негде, на крају света (2012) и збирка прозних минијатура О бабама и жабама (2013).

Сатира Вавилонски неимари није текст намењен деци нити младима, па га овде нећу посебно разматрати. Поменућу само укратко поступак његове конструкције, будући да је нешто слично препознатљиво и тексту Лет лионског Икара. Већ жанровска одредница у поднаслову сатира - доводи овај текст у везу са одређеном књижевном традицијом, али та веза је много конкретнија: Вавилонски неимари су писани на фону сатире Вођа Радоја Домановића. Подужим цитатом из Домановића приповедање и почиње, а потом се наставља кроз неку врсту имитације Домановићевог текста: приповедање тече углавном у аористу, безимени ликови означени су само збирним или редним бројевима, приповедање се смењује с кратким дијалозима. Мало-помало, међутим, текст задобија другачију физиономију, која га удаљава од предлошка. Домановићевска подлога бива контаминирана другим интертекстуалним наслагама: пре свега легендом о Вавилонској кули, а потом и бројним референцама из књижевности и културе. Оно што је испрва личило на имитацију постаје интертекстуални колаж, који ипак чува везу са прототекстом.

\footnotetext{
${ }^{4}$ Иако је обимом прекратко за уобичајено поимање романа, ово хибридно дело би најбоље било овако одредити, будући да се ради о тексту чије су епизоде чвршће повезане него што би то било у збирци прича.
} 
Аутобиографски текст Попа Д. Ђурђева „Тамо негде, на крају света", написан за збирку текстова који су својеврсни портрети уметника $y$ младости, ${ }^{5}$ сасвим је умерено интертекстуалан. У њему се кроз седам поглавља и кроз аутобиографски дискурс излажу сећања једног нушићевски немогућег дечака, потоњег писца П. Д. Ђ. Тек понегде су ове догодовштине гарниране понеком литерарном или културолошком референцом - нпр. кад приповедачево одрасло ја примећује како су га „вештице” из комшилука „обасипале пажњом ко Розмарину бебу” (116), или кад исти тај глас каже: „Ја нисам имао свог Симу Сарајлију, као Јован Јовановић, па да ми прорекне да ћу бити песник, али сам зато рођен као - Змај" (132). Следи догодовштина из детињства приповедачевог деде због које је заслужио надимак Змај, што је прешло у породични надимак. Куриозитет и коинциденција, кад знамо колико је песничка и професионална биографија Попа Д. Ђурђева повезана са Змајем, и то оним Ј. Ј. Понегде аутор цитира - Саројана, Лазу Костића, Стевана Пешића, А. Б. Шимића, али није то интертекстуалност какву иначе срећемо у његовом делу алузивна, иронична, пародијска. Она је овде углавном део информативног исказа, приповедања напросто. Најдужи цитат је цела песма, Мали Стева, сентиментално-морбидна траума из приповедачевог детињства, један од оних поступака којима родитељи, како је то кроз властиту трауму објаснио Данило Киш, у душу детета знају да посеју семе смрти.

Од ових информација разликује се, донекле, блиц-интертекстуално позивање на Малог принйа, односно на једну личност из његовог универзума:

Не сећам се какав је био положај планета на Велики петак 1953. Можда зато што је било скоро подне, па онај Сент-Егзиперијев фењерџија није имао разлога да пали своје карбит-лампе, али биће да сам се родио под неком од срећнијих звезда из галаксије мог заштитника Марса (136).

И све то приповедање напросто тече мирно до последњег, седмог дела текста. До момента кад постане метафикција. Приповедачки глас прича о својој фасцинацији ефектом умножавања слика, оличеном у лименој кутији на којој је нацртана девојка која у рукама држи исту такву кутију, на којој је девојка која држи исту такву кутију, на којој је... и тако у бескрај. Одједном се у тексту појављује и особа коју приповедач означава као „моја жена”, која, очигледно, слуша његово излагање: коњи...?

- Нисам чула то последње - довикује ми жена из кухиње. - Крилати

\footnotetext{
${ }^{5}$ Краљевачка Повеља, за коју је текст написан, годинама негује овај књижевни вид, тражећи од писаца да фикционализују нека од својих сећања из детињства. Тиме ови текстови губе својства аутобиографије sensu stricto и функционишу као аутоисповедна приповедна проза.
} 
Писац-приповедач наставља, али прича више није иста: мало-помало постаје очуђена. За доживљаје из детињства више се не би могло мирне душе рећи да припадају сфери реалног. Дечак из циркуса којег приповедач (доживљајно ја) среће погађа његове мисли, довршава његове реченице, има његову хармонику која је изгубила памћење. Овај снолики низ металептички прекида жена одраслог приповедача питањем: „Је л’ ти то спаваш?”. Али приповедач неће даље читати, он ће жени показати шта је даље било. Одлазе у Ковиљ, позорницу приповеданих догађаја, али тамо, очекивано, ништа није као пре. Уместо да се разочарају, међутим, њих двоје ће реконструисати оно чега нема 6 , па се у завршници ове фикционализоване мини-аутобиографије као у сабирном сочиву сустичу слике из претходних прича: приповедачева жена ће кроз фотографију отеловити (лажни) бескрај лимених кутија са сликама које се понављају, а у самом лирском финалу, док од звездане прашине жито сазрева преко ноћи, „Из правца економије, ка Аркању, кретао се полако црвени комбајн, на коме је писало ЗМАJ" (142).

О бабама и жабама, збирка прозних минијатура7, кратких записа са поентом, намењена је, као што је већ поменуто, основцима са високом стручном спремом. Ова одредница може се читати двојако: жељени читаоци с једне стране могу бити ученици основношколског узраста који много знају, а с друге одрасли, високообразовани, који су успели да остану деца, основци. Опрема књиге и библиотека у којој је објављена упутиће нас на дечју полицу у књижарама и библиотекама, али, као и иначе код Попа Д. Ђурђева, ствари нису тако једноставне и једнозначне. На почетку збирчице стоји реч аутора, која позива на чуђење. Радозналост и чуђење, одреднице које спајају филозофију ${ }^{8}$ и детињство, јесу conditio sine qua non срећног живота. „Кад престане чуђење, више ничега нема” (ĐURĐEV 2013: 5). Не треба дозволити да дете у човеку порасте, јер ако порасте, заборавиће да ce смеје" (ibid.). Али то Ђурђевљево дете, ма колико година имало, није ни наивно ни заглибљено у мочвари незнања. Оно мора да зна да би схватило Попове фазоне, па да би могло да им се насмеје. Интертекстуалност у њима то захтева, па ако се не схвати текст испод - пропаде фазон.

У минијатурама наилазимо на репертоар досетки познат из поезије овог писца: ту су игре речима, логои, дословна тумачења фраза, реализа-

${ }^{6}$ Разочараног писца, који увиђа да место на које су дошли нема много везе са светом његовог детињства, жена опомиње цитатом: „Знаш како је говорила Десанка: Ко хоће да доживи чудо, ииај мора вероваиии да она йосйоје" (142).

7 Аутопоетички запис на крају, назван „Нешто као по(п)говор или отворено писмо читаоцу” одређује их као „Езоо(п)теричне приче”, односно „генетски модификоване минијатуре, донекле налик баснама какве је некада у античкој Грчкој писао Езоп” (ĐURĐEV 2013: 73).

${ }^{8}$ Наравно, реч је о античком thaumazein, као предуслову филозофског мишљења. 
ције метафора, алузије, цитати итд. Аутор помаже младом читаоцу тако што уз евентуално непозната имена ставља звездицу и објашњење. Тиме остварује едукативну функцију коју интертекстуалност у књижевности за децу може и треба да има. ${ }^{9}$ Уместо да се дете држи подаље од текстова вишег реда зато што „не зна”, на адекватан начин му се омогућује да сазна. Награда за сазнање долази одмах, у виду разумевања досетке. Ипак, објашњења не могу бити довољна за сваког, иначе би текст био преплављен фуснотама. Досетке се не отварају сваком читаоцу једнако - на пример, у минијатури „Црно-бела прича и по” већина читалаца вероватно прати игру фразама „црна овца” и „бела врана”, али ако неком није позната песма „Гавран” Едгара Алана Поа, неће схватити завршетак који гласи: „Никад више!” (ĐURĐEV 2013: 11). Уосталом, тако је и у књижевности за одрасле - Име руже некима је само детективска прича у средњовековном бекграунду.

Ови кратки прозни текстови су и метафиктивни. Тако минијатура „Понављање је мајка мудрости” доноси разговор папагаја, сове и дечака у који се умеша писац, а фраза „крај приче” аутореференцијално се увphe и значи крај ове приче (ĐURĐEV 2013: 30). Једна минијатура зове се „Умало да ову причу изгубим из вида”, а у њој се дешава „невиђен сусрет” ћораве коке и слепог миша". Да се којим случајем нису срели, коментарише приповедачки глас, „ове приче не би ни било” (ĐURĐEV 2013: 48). У минијатури „Ко нема у глави, ту ни ноге не помажу” незадовољни кенгур одлази са места догађаја, „не сачекавши крај приче” (ĐURĐEV 2013: 67).

Коначно, највише аналитичке пажње у овом раду биће посвећено делу које је цело састављено од других текстова, а у тој усмерености ка другима усмерено је и на себе као на текст.

Дело Лет лионског Икара настало је пригодом - написано је поводом 110. годишњице рођења Антоана де Сент Егзиперија. Поводом

\footnotetext{
9 „Дете које чита овакву врсту литературе ће се током свог читалачког пута сетити књижевности Попа Д. Ђурђева као својих првих корака у књижевности, који ће му бити путоказ за даље развијање читалачких интересовања" (ДРАКУЛИЋ 2014: 88). Наташа Дракулић у свом приказу констатује: „Основа на којој је изграђена ова књига је пре свега интертекстуалност" и помиње мноштво аутора који су део овог Ђуђевљевог интертекста (ibid.). Весна Алексић у свом приказу каже: „Поп Д. Ђурђев много тражи од својих млађаних читалаца и сасвим је у праву! Можда би било идеално да ову књигу читају заједно бар две генерације у кући (...) Разумећете све ако се усудите. За неке од њих, писац ће вам објаснити коју књигу морате прочитати да бисте схватили штос, за неке, објасниће вам мит; за неке, мораћете да знате одређену музичку нумеру или одређен наслов из песничких збирки... У сваком случају, баш свако ово мало штиво натераће ваш ум да 'врти' великом брзином, пре него што се слатко насмејете. То је поступак, то је намера. То је управо оно што овог песника одваја од осталих: он не признаје читаоце аматере!” (ALEKSIĆ 2013: 21).
} 
ремек-дела славног француског пилота настало је ремек-делце, како Ђурђевљев роман квалификује Анђелко Ердељанин, и сажето га описује: „Примењујући технику пастиша (превасходно сликарску), подражавајући до извесне мере (и баш с мером!) стилске особине творца Малог принца, Ђурђев исписује низ дијалога писца (пилота) и златокосог дечака (Малог принца) који се као воде у неком потоњем оностраном времену и простору" (ERDELJANIN 2010: 88).

Лет лионског Икара већ на перитекстуалном нивоу најављује интертекстуалне релације. Прво, у наслову се помиње Икар, митски летач који је стремио превисоко и настрадао. Још ужа интертеркстуална веза најављена је поднасловом: „Ђулићи и увеоци Антоана де Сент-Егзиперија”, а потом и мотом: „Сваку нашу срећу / Страшна авет вија: Испод сваког цвета / Скривена је змија" (Јован Јовановић Змај, Ђулићи увеоци, XLII). Класична компаратистика, са својом теоријом утицаја, остала би збуњена пред овом зачудном везом: шта то имају заједничко Змај и Сент Егзипери? Одговор се - додуше, не онај који би задовољио теорију утицаја - може наћи већ у наведеном перитексту: то су мотиви руже и змије. Недовољно? Не ако је у питању Поп Д. Ђурђев и његова монтажа атракција. Мотив руже, осим у самој причи о писцу и принцу, присутан је и на сваком од петнаест фото-колажа који прате поглавља овог романа. ${ }^{10}$ Осим ружа, на колажима су и Мали Принц, писац и његова супруга Консуело, салвадорска ружа. Змије на сликама нема, нема је ни у тексту, али сваки читалац Егзиперијевог романа зна да је управо она Малог принца одвела кући. Њено минус-присуство одговара неименовању - или изоколном именовању - смрти у текстовима који чине овај интертекст: у свом последњем лету писац-пилот се такође враћа кући, као што смрт од ђулића чини ђулиће увеоке. Присуство Консуело, и на фотографијама и кроз алузије у тексту, својеврсна је металепса ${ }^{11}$, али и постмодернистичко укључивање некњижевног материјала у текст. Овог пута то су сведочанства о улози пишчеве супруге у креирању света Малог принща, пре свега кроз лик руже. ${ }^{12}$

У компаративној студији о Данилу Кишу и Антоану де Сент Егзиперију (DELIĆ 2016), Јован Делић детаљно анализира опсесивни мотив руже код двојице писаца. Нигде у тој анализи не помиње Сент Егзиперијеву супругу као ружу. И нема зашто да је помиње. Ње нема нигде у тексту. Истина, начин на који Мали Принц говори о ружи намеће по-

\footnotetext{
${ }^{10}$ Као и сам Мали йрини, и Лей лионског Икара је интермедијално дело. Док је прво употпуњено пишчевим акварелима, у друго су, сходно поетици његовог аутора, уклопљени фото-колажи.

${ }^{11}$ О металепси види: ŽENET 2006.

${ }^{12}$ Из заоставштине Консуело де Сент Егзипери су 2000. године објављени Мемоари руже.
} 
ређење са женом ${ }^{13}$, али она се не доводи у везу са Сент Егзиперијем. Податак да је лик руже инспирисан пишчевом супругом јесте вантекстуална чињеница која спада у домен позитивистичке критике, и као таква је за владајућу парадигму науке о књижевности поприлично passé. Начин на који је Поп Д. Ђурђев користи у свом роману даје јој другу димензију и на сасвим легитиман начин је чини делом текста. Он је пре свега уноси као слику, и она је у овом интермедијалном делу, уз ружу, доминантан визуелни мотив. Уноси је и у текст кроз дискретне алузије, а разрешење долази на крају, у запису писия ${ }^{14}$, означеном знаком ?. Најдужи део посвећен овој биографској интерполацији јесте прича о вулканима, у дословном и пренесеном значењу. Писац помиње „свој мали вулкан”, о ком „се не прича пред децом” (IV). Тај вулкан је и ружа, и лисица, и змија, на шта Мали Принц прави маестралну варијацију змијског цара који је прогутао слона: „Она је змија која је прогутала вулкан и лисицу, па сад изгледа као раскошни женски шешир украшен цветом руже” (IV).

Може бити да је, како тврди Анђелко Ердељанин у приказу Ђурђевљевог дела, повлачење паралеле између Змаја и Сент Егзиперија „ново питање за теоретичаре дечје књижевности” (ERDELJANIN 2010: 89). Ипак, у анатомији овог текста Попа Д. Ђурђева довољан је механизам асоцијације, којим су изграђене многе његове песничке творевине. Кад би постојао некакав интерлитерарни Google преводилац, ако бисмо на једној страни укуцали „ружа” и „смрт”, што јесу доминантни мотиви Ђурђевљевог текста, на другој страни би могло изаћи: ђулић увелак. Веза којом су ова два писца доведена у контакт пре свега је визуелна и звучна, резултат је „вербовоковизуелних истраживања” ${ }^{15}$ Попа Д. Ђурђева, па би класична компаратистичка детекција овде вероватно била јалов посао.

Поп Д. Ђурђев жели да поверујемо да је свој интертекст начинио као имитацију, или још боље, емулащију. ${ }^{16}$ Зато роман, попут Сент Егзи-

\footnotetext{
${ }^{13}$ У Дейиюсивву је објављен текст Јелене Стефановић, писан са становишта феминистичке критике (STEFANOVIĆ 2016), који указује на патријархално схватање жене у Малом ирринцу управо кроз анализу односа Малог Принца и Руже.

${ }^{14}$ Овог пута не Сент Егзиперија већ Попа Д. Ђурђева.

${ }_{15}$ Израз Милоша Јоцића за песничке ребусе Попа Д. Ђурђева, који се, очито, може применити и на његову прозу (в. JOCIĆ 2013: 5).

${ }^{16}$ Емулација (aemulatio), термин који се као допуна појму имитације афирмисао у римској реторици у 1. веку н. е. Означавао је подражавање у којем су се амбициозни писци или говорници такмичили са својим узорима покушавајући да их достигну па и надмаше. „Тиме се засновао амбивалентан однос према егземпларном моделу, разапет између респектабилног праћења и воље за његовим превазилажењем и прекрајањем. Подражавање је с такмичењем (конкуренцијом) све до краја 18. века импликовало да потоњи говорник или песник у улози читаоца узор најпре тумачи на свој начин, као стваралац га потом присваја и - без обзира на његову језичку, социолекталну историјску или културну удаљеност - искоришћава за стварање текста намењеног другачијим
} 
перија, дели на сегменте означене римским бројевима. Истина, број није исти. Резултат је $27: 13^{17}$ за Егзиперија. Донекле, имитиран је и Егзиперијев стил. Мали Принц и овде поставља питања због којих наш и Сент Егзиперијев свет делују зачудно, изговара мудрости које би, као и оне из оригиналног Малог принца, могле да уђу у the best of антологијице комерцијалних издавача, а писац-авијатичар му у томе парира. Али све је то само донекле. Лик који је овде „Сент Егзипери” повремено се претвара у сатиричара, или у и колажисту који се игра асоцијацијама. Такве неке субјекте, углавном лирске, упознали смо у поезији нареченог П. Д. Ђ. Примесе сатире примећујемо углавном онда кад је реч о рату. Тако се авијатичар надовезује на Принчев аутоцитат:

- Кад неко хоће да има овиу, то је доказ да постоји. ${ }^{18}$

- Наравно. А кад овца хоће да докаже другој овци да постоји, она започне par. ${ }^{19}$

- Зар баш мора?

- Не мора, али то изгледа једино зна. То је, као, питање опстанка (II).

Из ове приче развија се и пример мешања асоцијација и неочекиваног обрта „унижавањем” тренутка:

- Да је више цртача, можда ратова не би ни било.

- Можда?

- У том случају моја ружица...

- Трнова ружица!

- Да, трнова ружица, могла би да посече своје бодљикаве канџе и слободно изађе испод стакленог звона.

- Би, али само ако наиђе мали принц на Пегазу и донесе јој на поклон прибор за нокте (II).

Или још једно типично „поповско” претрпавање интертекстуалних асоцијација:

... Само небеска пространства су бескрајна. Па звезде...

- Постоје и морске звезде.

- Али те звезде не умеју да се смеју.

- Да сам отишао у морнарицу можда бих их научио.

- У том случају нас двојице не би било. Ти би био неко други. Дружио би се са Малом сиреном...

\footnotetext{
релацијама и публици" (JUVAN 2013: 61-62).

17 Уз тринаест поглавља П. Д. Ђ. иду и два додатка, означена упитником односно узвичником.

${ }^{18}$ Реченице из Малог йринца доследно су цитиране курзивом.

${ }^{19}$ Пре овога писац каже како се на његовој планети одвија „рат између оваца и оваца”, а не између оваца и цвећа, како мисли Мали Принц (II).
} 
- И био Ружно паче.

- Да, ствари се могу и тако посматрати, мада... Од сваког треба захтевати оно што он може да пружи (VII).

Овај део могао би да стоји самостално у некој књизи минијатура Попа Д. Ђурђева, налик на ону О бабама и жабама. Другим речима, овај део наизглед имитираног дискурса у потпуности носи ауторски печат П. Д. Ђ. и озбиљно уздрмава утисак о имитацији.

Мали прини је текст који обилује дијалозима, али Лет лионског Икара иде корак даље: у њему, ако изузмемо записе аутора на крају, нема ничег осим дијалога. Могла би се на основу тога и довести у питање тврдња да је реч о прозном делу - оно пре изгледа као драмски текст из којег су изостављене дидаскалије, па и ознаке за лица. Због овог потоњег је читалац приморан да се поприлично потруди како би схватио ко говори. Понекад је потребно кренути из средине - наћи реплику која недвосмислено припада Малом Принцу или његовом писцу, па на основу тога идентификовати исказиваче. У Лету лионског Икара реч је о другом сусрету писца и Принца. Дијалози почињу in medias res, а околности и разлог овог поновљеног сусрета откривају се тек постепено. Оно што је већ од првог фрагмента јасно јесте да су и Принц и писац свесни постојања къиге која је настала између ова два сусрета. Двојица јунака се међусобно цитирају и тога су свесни. Тако Мали Принц каже: „Одрасле особе никад ништа не разумеју... Надам се да не морам даље да те цитирам" (I). Не треба заборавити да је и у самом Малом приниу присутна приповедачева/ауторова свест о књизи. То није видљиво само из посвете Леону Верту „кад је био мали дечак” већ и из других делова текста. Тако у четвртом фрагменту писац каже:

Волео бих да сам ову причу почео као бајку. Волео бих да сам рекао:

- Био једном један мали принц и живео је на планети која је једва нешто мало већа од њега самога, а био му је потребан пријатељ.

Онима који разумеју живот то би се чинило много уверљивије.

Јер ја не волим да се моја књига чита површно (22-23).

Поред свести о писању, писац са имплицитним читаоцем дели и свест о цртағу, па му износи своје дилеме везане за (не)могућност да, будући лаик - а уз то још и давно као цртач обесхрабрен неразумевањем одраслих - верно представи лик Малог Принца. ${ }^{20}$ УЛету лионског Икара јунаци се осврћу на књигу, помињу се околности њеног настанка, нпр.

\footnotetext{
20 „Понеки цртеж ми успе, други опет не личи ни на шта. Исто тако се преварим и у погледу стаса (...) Преварићу се, уосталом, и у неким важнијим детаљима. Али то ми морате опростити. Мој пријатељ никада ништа није објашњавао. Можда је веровао да сам му сличан. Али ја, нажалост, нисам способан да видим овцу кроз кутију. Можда сам помало сличан одраслим особама. Мора бити да сам остарио" (23).
} 
када писац прича о цртежу који је нацртао у Америци, пред својим издавачем Кертисом Хичкоком. Помињу се и друге особе из пишчевог „стварног света", као што је његов пријатељ Леон, а у загонеткама и већ помињана пишчева супруга. Ове металептичке упадице додатно релативизују већ уздрмани онтолошки статус јунака - писац (понекад) мисли да Мали Принц није стваран, Мали Принц то можда мисли о њему, али у разговор укључују оне који (ваљда) недвосмислено насељавају пишчев „стварни свет”. Али Кертис Хичкок овде није само металептички уљез из стварности већ и лик из света Малог Принца - пословни човек који мешетари звездама. Биографски податак, упадица из спољашњег света, у колажном делу Попа Д. Ђурђева се, слично као и лик Консуело, уклапа у фикцију и постаје део књиге.

Треће и пето поглавље књиге на велика врата уводе метафикцију. Ако следимо дефиницију Патрише Во, реч је о писању које „самосвесно и систематски скреће пажњу на свој статус артефакта, како би поставило питање о вези између фикције и стварности" (VO 1984: 2). Дилема овде гласи: је ли писац створио Принца или Принц писца? Писац, очекивано, пита: „Зар књига о теби није доказ да сам те ја измислио?” (III). У репликама се меша неколико традиционалних и мање традиционалних „доказа постојања": постојим зато што си ме ти измислио, постојим зато што сам хтео да имам овцу, картезијански доказ из сумње и чињеница да је неког родила мајка. У једном тренутку писац изјављује да Мали Принц није стваран и да он, у ствари, разговара са самим собом. Али и Мали Принц зна за јадац, па поставља кључно питање ове метафиктивне полемике:

- А шта ако су и тебе измислили, ако је и твој живот само књига? (III).

Писац се позива на реалије из свог живота, а Принц опет на неку варијанту Декартове обмане злог демона кад упућује на непоузданост чулних утисака, туђих сведочанстава и сећања. Али ово није филозофска већ метафиктивна расправа, па Мали Принц, као одговор на пишчево позивање на меморију, каже:

- То је оно што си прочитао о себи. Ти једино не знаш како ће се књига завршити.

- А ти знаш?

- Знам. Као што си ти знао како се завршава књига о мени, тако и ја знам како ће се зршити књига о теби.

- Ми смо, значи, један другог прочитали (III).

Али чини се да ни писцу ни Принцу, на крају крајева, није важно ко је ту кога измислио. Постоји нешто важније од питања постојања, а то је пријатељство, макар оно било и металептичко. Њих двојица су један другог припитомили, и због тога су заувек одговорни један за другог. По- 
стмодернистичко релативизовање граница између стварног и фиктивног света овде је и са̂мо релативизовано, чињеницом овог транстекстуалног пријатељства. Или кроз парафразу: Добро је ито човек има пријатеља, чак и кад је он јунак његове властите кюиге.

Већ из другог фрагмента постаје јасно да се други сусрет два пријатеља одвија за време рата. Писац и Принц су заједно у авиону и извиђају покрете непријатељских снага. Из птичје перспективе посматрају море. У разговоре о различитим темама, већином сличних онима које су покретане и у самом Малом приниу, увлачи се прича о смрти. Писац наговештава да је његов крај можда близу и парафразира реченицу Малог Принца: „Хоћеш рећи, изгледаћу као да сам мртав, а то неће бити истина..." (XI). У следећем, претпоследњем нумерисаном фрагменту, схватамо да присуствујемо погибији пилота:

- Да ли је то неко отворио ватру на нас?

- Не знам, нисам ништа приметио. Гледао сам звезде.

- Учинило ми се као да је апарат погођен (XII).

Ревносни пилот жели да изврши задатак и надлети сектор још једном, али на његово чуђење команду преузима Мали Принц:

...Откуд ти знаш да управљаш летилицом?

- Када сам могао да управљам јатом птица, могу и машином.

- Чекај, нешто није у реду.

- Знам да није у реду, зато све препусти мени (XII).

Пут на који су кренули Мали Принц и пилот, у још једном измењеним улогама, јесте пут у смрт, али то се ни у овом делу не зове тако:

- Доста је било те приче. Скидај ту капу, опасач, наруквицу, све... Твоје тело је ионако сувише тешко.

- За шта?

- За пут.

- Какав пут?

- Далек. Данас се са мном враћаш кући (XII) ${ }^{21}$.

У последњем нумерисаном делу писац и Мали Принц су заједно на астероиду В 612, који је, очито, сада постао и пишчев дом. Има ли боље post mortem судбине једног писца? Смрт је нови почетак: на помен овце Мали Принц, пола у курзиву а пола у куренту, каже: „Молим вас... нацртај ми још коју!, на шта писац одговара: „Не почињи опет све испочетка.” Кад буду имали много оваца, тераће небом бела стада, да пре-

${ }^{21}$ Овде је на делу још један реципроцитет: као што је писац присуствовао несшанку Малог Принца, и Мали Принц присуствује несйанку писца-пилота. Не треба заборавити ни чињеницу да је погибија Антоана де Сент Егзиперија 31. јула 1944. до данас остала предмет нагађања и мистификација. 
крате време док се на пишчевој планети не заврши рат. Писац и Принц још једном замењују улоге и кад Принц пита Писца: „Недостаје ти твоја ружа?". Писац пак тврди како му највише недостају новине, јер жели да види како ће у сутрашњем броју Пари Соара извештавати о његовом нестанку. У овој бизарној ситуацији двојица пријатеља нагађају наслов будућег чланка. Принц користи цитат из „оригинала” - „Чини се да је за своје бекство искористио сеобу птица”, док писац предлаже „Лет лионског Икара" и тиме удара последњи клин у овај метафиктивни ковчег. Али упркос причи о смрти, у њему нису два мртваца, јер књижевни ликови не могу да умру. Захваљујући Попу Д. Ђурђеву и писац-пилот је постао књижевни јунак, па је и његов живот постао књига.

Након документарног додатка о случају Сент Егзипери, следи одјавна реч писца, али овог пута не писца Малог принцза већ писца Лета лионског Икара. Завршни део текста Малог принцза у потпуности је поновљен ${ }^{22}$, наравно курзивом, а једини додатак, курентом, гласи: „Вероватно ће у његовом (Малог Принца, прим. М. К.) друштву бити и један пилот." Два јунака захтевају граматичку множину, па је због тога незнатно измењена последња реченица: „Будите онда добри! Не остављајте ме тако тужног: пишите ми брзо да су се вратили..." Последњи ред у књизи потпуно је огољена металепса, и то металепса аутора Лета лионског Икара - то je e-mail адреса nspop@eunet.rs.

У Лету лионског Икара сажето је драматизована цела постмодерна поетика: непостојаност питања ауторства, несигурност граница између примарног и секундарног света у књижевном делу, заснованост текста на другим текстовима, свест дела о себи као артефакту. Кероловска дилема о томе ко је кога сањао овде је отворено формулисана као питање ко је кога створио - писац јунака или јунак писца.

Питање би могло да гласи и - ко је кога прогутао: змијски цар слона, Мали Принц писца, писац Малог Принца, или Поп Д. Ђурђев све њих заједно? Читалац који је позван да покуша да одговори на то питање мора да увежбава способност да види овцу кроз кутију. Ако одговор и не нађе, уживаће у тражењу.

\section{Цитирана литература}

ALEKSIĆ 2013: Aleksić, Vesna. „O babama i žabama”. Bibliotečki putokaz, god. IX, sv. 29-30 (2013): 21. [orig.] Алексић, Весна. „О бабама и жабама”.

22 Поновљен је и део који у Летиу лионског̈ Икара нема референта. Испод цртежа на ком је место појављивања и нестанка Малог Принца пише: „То је исти предео као на претходној страни, али сам га ја још једанпут нацртао да бих вам га добро показао." У књизи Попа Д. Ђурђева тај цртеж се појављује само на том месту, не и на претходној страни. 
Библиотечки путоказ, год. IX, св. 29-30 (2013): 21.

DELIĆ 2016: Delić, Jovan. „Danilo Kiš i Antoan de Sent-Egziperi”. U: Danilo Kiš. Osamdeset godina od rođenja (1935-2015). Radovi sa naučnog skupa, Podgorica, 15-16. oktobra 2015, Podgorica, 2016, str. 15-40. [orig.] Делић, Јован. „Данило Киш и Антоан де Сент-Егзипери”. У: Данило Киш. Осамдесет година од рођења (1935-2015). Радови са научног скупа, Подгориияа, 15-16. октобра 2015, Подгорица, 2016. стр. 15-40.

DRAKULIĆ 2014: Drakulić, Nataša. „Kreativna igra sa babama i žabama”. Detinjstvo, god. XL, br. 3 (jesen 2014): str. 87-88. [orig.] Дракулић, Наташа. „Креативна игра са бабама и жабама”. Детиюство, год. XL, бр. 3 (јесен 2014): стр. 87-88.

ERDELJANIN 2010: Erdeljanin, Anđelko. „Dijalog pisca i princa”. Detinjstvo, god. XXXVI, br. 4 (zima 2010): str. 88-90. [orig.] Ердељанин, Анђелко. „Дијалог писца и принца”. Детиюство, год. XXXVI, бр. 4 (зима 2010): стр. 88-90.

JOCIĆ 2013: Jocić, Miloš S. „Rebus poezija Popa D. Đurđeva”. Detinjstvo, god. XXXIX, br. 3 (jesen 2013): str. 3-9. [orig.] Јоцић, Милош С. „Ребус поезија Попа Д. Ђурђева". Детињство, год. XXXIX, бр. 3 (јесен 2013): стр. 3-9.

JUVAN 2013: Juvan, Marko. Intertekstualnost. Sa slovenačkog prevela Bojana Stojanović Pantović. Novi Sad: Akademska knjiga, 2013.

MAKOVIĆ, MEDARIĆ i dr. (ur.) 1988: Intertekstualnost \& intermedijalnost. Uredili: Zvonko Maković, Magdalena Medarić, Dubravka Oraić i Pavao Pavličić. Zagreb: Zavod za znanost o književnosti, 1988.

MEKALUM 2013: Mekalum, Robin. „Tekstovi višeg reda: metafikcija i eksperimentisanje tekstom", u: Piter Hant (ur.), Tumačenje književnosti za decu, priredila Zorana Opačić, prevela Nataša Janković, Beograd: Učiteljski fakultet, 2013, str. 217-237. [orig.] Мекалум, Робин. „Текстови вишег реда: метафикција и експериментисање текстом”, у: Питер Хант (ур.), Тумачење књижевности за деиу, приредила Зорана Опачић, превела Наташа Јанковић, Београд: Учитељски факултет, 2013, стр. 217-237.

NIKOLAJEVA 1996a: Nikolajeva, Maria. "Intertextuality in Children's Literature", in: Children's Literature Comes of Age, New York and London: Garland Publishing, Inc., 1996, 153-187.

NIKOLAJEVA 1996b: Nikolajeva, Maria. "Metafiction in Children's Literature", in: Children's Literature Comes of Age, New York and London: Garland Publishing, Inc., 1996, 189-206.

ORAIĆ TOLIĆ 1990: Oraić Tolić, Dubravka. Teorija citatnosti. Zagreb: Grafički zavod Hrvatske, 1990.

RADONIČIĆ 2013: Radoničić, Ana K. „Intertekstualnost u poeziji Popa D. Đurđeva”. Detinjstvo, god. XXXIX, br. 3 (jesen 2013): str. 9-21. [orig.] Paдоничић, Ана К. „Интертекстуалност у поезији Попа Д. Ђурђева”. Детиюство, год. ХХХІХ, бр. 3 (јесен 2013): стр. 9-21. 
RADULOVIĆ 2006: Radulović, Olivera. „Biblijski podtekst u romanu Mali princ Antoana de Sent Egziperija”. Detinjstvo, XXXII, br. 2 (proleće 2006): str. 3-8. [orig.] Радуловић, Оливера. Библијски подтекст у роману Мали прини Антоана де Сент Егзиперија. Детиюство, год. XXXII, бр. 2 (пролеће 2006): стр. 3-8.

STEFANOVIĆ 2016: Stefanović, Jelena Z. „Ruže nikad ne treba slušati, treba ih gledati i mirisati”. Detinjstvo, XLII, br. 1 (proleće 2016): str. 95-101. [orig.] Стефановић, Јелена 3. „Руже никад не треба слушати, треба их гледати и мирисати". Детињство, год. XLII, бр. 1 (пролеће 2016): стр. 95-101.

STOLIĆ 2015: Stolić, Danica V. „Palimpsest i vizuelizacija kao postupci dekanonizacije u pesništvu Popa D. Đurđeva". Detinjstvo, god. XLI, br. 4 (zima 2015): str. 34-40. [orig.] Столић, Даница В. „Палимпсест и визуелизација као поступци деканонизације у песништву Попа Д. Ђурђева”. Детиюство, год. XLI, бр. 4 (зима 2015): стр. 34-40.

VILKI 2013: Vilki, Kristin. „Povezanost tekstova: intertekstualnost”, u: Piter Hant (ur.), Tumačenje književnosti za decu, priredila Zorana Opačić, prevela Nataša Janković, Beograd: Učiteljski fakultet, 2013, str. 205-216. [orig.] Вилки, Кристин. „Повезаност текстова: интертекстуалност”, у: Питер Хант (ур.), Тумачење књижевности за деиу, приредила Зорана Опачић, превела Наташа Јанковић, Београд: Учитељски факултет, 2013, стр. 205-216.

VO 2001: Waugh, Patricia. Metafiction. The Theory and Practice of SelfConsciousness Fiction. London and New: Routledge (Taylor \& Francis e-Library), 2001.

ŽENET 2006: Genette, Gérard. Metalepsa. Od figure do fikcije. Prevela Ivana Franić, Zagreb: Disput, 2006.

\section{Извори}

ĐURĐEV 1984: Đurđev, Pop D. Vavilonski neimari. Satira. Novi Sad: Srpska čitaonica i knjižnica Irig, 1984.

ĐURĐEV 2010: Đurđev, Pop D. Let lionskog Ikara (Đulići i uveoci Antoana se Sent-Egziperija). Novi Sad - Zrenjanin: Zmajeve dečje igre - Gradska narodna biblioteka „Žarko Zrenjanin”, 2010.

ĐURĐEV 2012: Đurđev, Pop D. Tamo negde, na kraju sveta. U: Vidi čuda, I, priredila Gordana Timotijević. Beograd: Službeni glasnik, 2012, str. 113-142. [orig.] Ђурђев, Поп Д. Тамо негде, на крају света. У: Види чуда, I, приредила Гордана Тимотијевић. Београд: Службени гласник, стр. 113-142.

ĐURĐEV 2013: Đurđev, Pop D. O babama i žabama. Minijature za osnovce sa visokom stručnom spremom. Čačak: Pčelica. [orig.] Ђурђев, Поп Д. О бабама и жабама. Минијатуре за основце са високом стручном спремом. Чачак: Пчелица. 


\section{Mirjana S. Karanović}

"BUT WHAT IF YOU ARE MADE UP AS WELL, IF YOUR OWN LIFE IS ONLY A BOOK ?" Intertextuality and metatextuality in the fiction of Pop D. Đurđev

Pop D. Đurđev's fiction, like his poetry, is extremely intertextual. Different forms of citation, parody, and irony are the most common forms of expressing the intertextuality in this fiction. As, according to Patricia Waugh, these elements can be seen as forms of metafiction, writings which "selfconsciously and systematically draws attention to its status as an artefact", we can conclude that the fiction of Pop D. Đurdev is metafictional as well. But it is metafictional also in the narrower meaning of that notion: in some texts, above all in Let lionskog Ikara (The Flight of the Lyonnais Icarus), the question of the relation between reality and fiction is discussed in a manner typical of the postmodern concept of author self-awareness: Who invented whom - did the author invented the hero, or vice versa?

Key words: Pop D. Đurđev, Antoine de Saint-Exupéry, intertextuality, metafiction, postmodern, rose, death 